\title{
UP-TO-DATE THROMBOPROPHYLAXIS IN ELECTIVE SPINAL SURGERY. A SYSTEMATIC REVIEW
}

\author{
ATUALIZAÇÃO EM TROMBOPROFILAXIA EM CIRURGIAS ELETIVAS DA COLUNA VERTEBRAL. \\ REVISÃO SISTEMÁTICA
}

\section{ACTUALIZACIÓN SOBRE LA TROMBOPROFILAXIS EN CIRUGÍA ELECTIVA DE COLUMNA. UNA REVISIÓN SISTEMÁTICA}

Leonardo Oliveira ${ }^{1}$, Luis Marchi ${ }^{1}$, Luiz Pimenta ${ }^{1}$

\begin{abstract}
Deep vein thrombosis (DVT) and pulmonary embolism (PE) present a high incidence after surgery, posing a high risk in surgical practice. Although a consensus does exist on thromboprophylaxis in orthopedic surgery, this topic remains controversial in regard to spinal surgery. In this current paper, we review and discuss the different forms of prophyilaxis presented in literature, in order to develop guidelines on prophylactic measures in spinal surgery, improving patient's outcomes and reducing any medical/legal problems that could arise from a thrombotic complication.
\end{abstract}

Keywords: Venous thromboembolism; Pulmonary embolism; Spine/surgery; Postoperative complications.

RESUMO

O tromboembolismo venoso (TEV) e a tromboembolia pulmonar (TEP) apresentam elevada incidência no pós-operatório, sendo de alto risco na prática cirúrgica. Embora já exista consenso sobre tromboprofilaxia em cirurgias ortopédicas, na cirurgia de coluna, a conduta ainda é controversa. Neste artigo, analisamos e discutimos as diferentes tromboprofilaxias publicadas na literatura, a fim de desenvolver orientações sobre medidas profiláticas em cirurgia da coluna, melhorando os resultados do paciente e reduzindo os problemas médico-legais que possam surgir a partir de uma complicação trombótica.

Descritores: Tromboembolia venosa; Embolia pulmonar; Coluna vertebral/cirurgia; Complicações pós-operatórias.

\section{RESUMEN}

La tromboembolia venosa (TEV) y la tromboembolia pulmonar (TEP) tienen alta incidencia en el postoperatorio, siendo de alto riesgo en la práctica quirúrgica. Aunque ya existe un consenso sobre la tromboprofilaxis en cirugía ortopédica de la columna vertebral, su manejo sigue siendo controversial. En este artículo analizamos y discutimos las diferentes tromboprofilaxis publicadas en la literatura, con el fin de elaborar directrices sobre la profilaxis en la cirugía de la columna vertebral, mejorar los resultados del paciente y reducir los problemas médicos y jurídicos que surgen de una complicación de la trombosis.

Descriptores: Tromboembolia venosa; Embolia pulmonar; Columna vertebral/cirugía; Complicaciones postoperatorias.

\section{INTRODUCTION}

Venous thromboembolism (VTE) is a well-known episode in surgical practice and represents a spectrum of diseases that includes deep vein thrombosis, thrombosis associated with central venous catheters, and its most serious complication, pulmonary thromboembolism (PTE). ${ }^{1}$ Both asymptomatic and clinically apparent episodes in hospitalized patients are associated with high mortality, and are the main cause of morbidity and mortality in the United States. ${ }^{2}$ In clinical practice, antemortem suspicion occurs in only a small percentage of PTEs, and the few cases followed up, together with the lack of literature, are insufficient to form solid experience and guidelines for the treatment of this event. ${ }^{3}$ The high incidence of VTE in surgical populations, besides the legal consequences, ${ }^{4}$ highlights the need for prophylaxis in this group of patients. ${ }^{5}$

Knee and hip replacement surgeries, and the surgical treatment of hip fractures, are associated with a high rate of VTE and a high mortality rate, despite the consensus on prophylaxis. ${ }^{6}$ However, little has been described in the literature concerning thromboembolic events and their prophylaxes in spinal surgeries, with only the risk factors for their occurrence being mentioned, without scientific confirmation of their postoperative implications. ${ }^{7}$ Another important factor related to thromboprophylaxis in spinal surgery is the increased risk of epidural hematoma in patients using prophylaxis with anticoagulants and thrombolitics. ${ }^{8,9}$ Therefore, this work aims to establish guidelines for the prevention of VTE in elective spinal surgeries, and to clarify the possible risks related to the use of the different preventative therapies, through a systematic review of the literature.

\section{METHODS}

A systematic review was conducted in accordance with the guidelines published by the Centre for Evidence-Based Medicine (available at www.cebm.net) and QUOROM (Quality of Reporting of Meta Analyses, available at http://www.greenjournal.org/misc/ quorom.pdf). An Ovid online search engine was used to search the Medline database from 1966 to 2013. The keywords used for the search were "Spine" and "Thrombosis".

Literature reviews, case reports, articles in languages other than English, and those related to anesthesia procedures, punctures, and traumas were excluded. The eligible studies were then reviewed in detail, and data was compiled for analysis and comparison, including study design, type of surgical procedure, number of patients, prophylaxis method used, incidence of VTE and PTE, and the level of evidence of the study.

1. Instituto de Patologia da Coluna, São Paulo, SP, Brazil. 


\section{RESULTS}

The initial search on the Medline database using the keywords "Spine" and "Thrombosis" identified 776 articles. Article reviews (90 articles) and case reports (301 articles) were excluded, leaving a total of 385 articles at the end of the initial analysis. Two of the authors reviewed the titles and abstracts of the remaining works, selecting those that satisfied the inclusion criteria. Only clinical trials related concomitantly to venous thromboembolism and spinal surgery were included, resulting in 31 articles. Publications in languages other than English or related to anesthetic procedures, punctures, and traumas were also excluded in this step. In the end, 26 eligible articles were reviewed in detail (Figure 1).

Of the 26 articles evaluated, 14 were prospective single-center studies and nine were conducted retrospectively, while one presented a retrospective analysis of data collected prospectively. Only two prospective, comparative, randomized studies were conducted. A total of 1,402,657 patients were evaluated across all these studies, all of whom underwent some type of surgical procedure of the spine. The surgical procedures performed in each study, as well as the prophylaxis used, the diagnostic methods, and the rates of VTE and PTE are described in Table 1. ${ }^{10-35}$

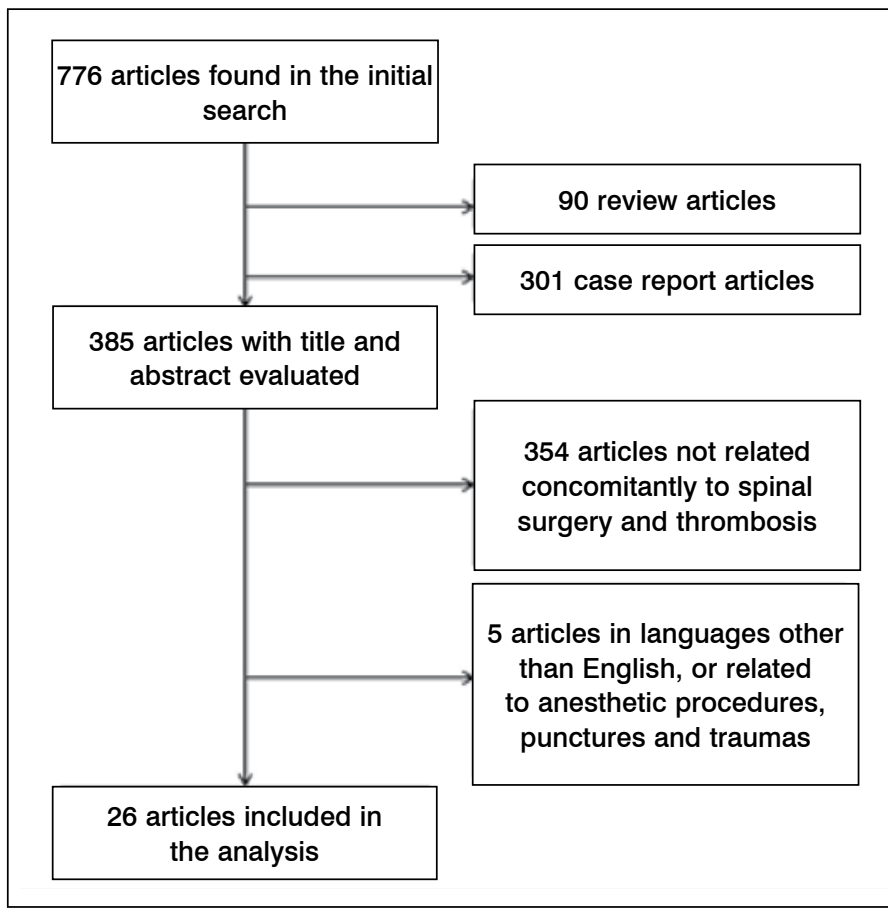

Figure 1. Search results in publications about thrombosis in spinal surgery using the Medline database.

\section{DISCUSSION}

The occurrence of VTE and PTE are common clinical situations with high relative prevalence in older age groups and in the hospital environment. Clinical manifestations may be absent, or even concealed or suggestive, and may be an incidental finding, a complication of high morbidity, or lead to sudden death. ${ }^{3}$ Deep vein thrombosis (DVT) and its most feared complication, pulmonary thromboembolism (PTE), still have a high incidence, and in PTE, deaths occur prematurely. There should be daily postoperative evaluations in search of symptoms that might indicate VTE or PTE. ${ }^{36}$

As is well known, the number of thrombotic events increases in surgical cases, with the risk ranging from 15 to $40 \%$ in neurosurgeries, reaching alarming rates of 40 to $60 \%$ in major orthopedic surgeries, according to the American College of Chest Physicians (ACCP). ${ }^{8}$ In spinal surgery, the incidence of DVT becomes more uncertain given the heterogeneity of the surgical procedures and the lack of precise literature. ${ }^{37-39}$ Our research uncovered only one study with level 1 evidence, in which Wood et al ${ }^{28}$ compared the use of pneumatic compression stockings with the use pneumatic thigh compression bandages. Although a control group was not used, the authors found lower rates of incidence of DVT and PTE than those found in the literature. However, there were no significant differences between the two prophylactic procedures tested, and the choice of method was made based on costs, ease of access, comfort, and preference of the medical team.

Yoshioka et $a /,{ }^{10}$ in their prospective comparative study, demonstrated that the incidence of DVT varies according to the region of the surgery and its approach. The cervical region presented a lower rate of complications, while spinal tumors requiring extensive excisions presented a higher rate of DVT. Other factors described in the literature, and that lead to an increased risk of DVT, include surgical time, longer periods of postoperative immobility, and ventral decubitus. ${ }^{24,37,40}$ Patient demographics are also an important factor contributing to the risk of DVT. Advanced age, male sex, presence of other comorbidities, such as congestive heart failure (CHF), and recent weight loss are independently associated with an increase in the rate of DVT complications. ${ }^{14}$ In contrast, Kim et a/ ${ }^{15}$ failed to demonstrate significant associations between demographic variables, comorbidities, and even between the type of surgical procedure and increased risk of VTE and PTE, showing a discrepancy in the results presented in the current literature and the absence of comprehensive works with higher levels of evidence. In our research, only one study was categorized as level 1 evidence according to the level of evidence criteria used by the scientific community. ${ }^{41}$

The average overall rates of VTE and PTE found in this review were $3.55 \%$ and $1.04 \%$, respectively. However, the heterogeneity of the studies prevents us from applying the numbers directly to spinal patients. Healthy patients selected clinically following less extensive procedures presented a low rate of DVT, ${ }^{30}$ while patients with one or more thromboembolism risk factors submitted to more substantial procedures with venography scans presented higher rates. ${ }^{24}$ The spinal surgeon should therefore weigh these different factors, estimating each patient's risk individually.

The most commonly used methods of prophylaxis are mechanical, such as compression by elastic compression stockings (ECS), intermittent pneumatic compression (IPC) and pneumatic foot pumps, and less frequently, chemical methods with low molecular weight heparin (LMWH) and low dose coumadin. In several articles, $32,34,33$ Ferree described the use of mechanical prophylaxis and found no significant statistical difference in rates of VTE, while in his prospective study, Epstein ${ }^{22}$ showed that intermittent pneumatic compression is effective in prophylaxis against VTE/PTE. Smith et $a /,{ }^{31}$ using a combination of elastic compression stockings and intermittent pneumatic compression, found no evidence of thrombosis in any of the 126 duplex ultrasound studies, and reported an overall clinical prevalence of thrombotic complications of $0.9 \%$ (3 patients in 317).

The number of studies that have investigated chemoprophylaxis is small and, coupled with the lack of suitable control groups and the significant heterogeneity of the populations studied, their results do not enable any conclusions to be drawn about the use of chemical anticoagulants in reducing thromboembolitic events. In contrast, Cunningham et al, ${ }^{17}$ comparing groups without prophylaxis and with chemoprophylaxis, found no statistical differences between them, suggesting that preoperative prophylaxis does not influence the rate of postoperative VTE and PTE.

Another important complication related to the use of chemoprophylaxis is symptomatic epidural hematoma, which usually presents rapidly progressing neurological deterioration and may be associated with coagulopathy induced by the administration of anticoagulants. ${ }^{42-44}$ Around $4 \%$ of patients who receive systemic LMWH prophylaxis develop hemorrhagic complications, compared with the $0.5 \%$ to $2.5 \%$ of patients who develop DVT following spinal surgery, ${ }^{40,45}$ making this a substantial disincentive for chemoprophylaxis following spinal surgery. ${ }^{9,46}$ 
Table 1. Summary of the 26 articles selected for inclusion in the systematic review. ${ }^{10-35}$

\begin{tabular}{|c|c|c|c|c|c|c|c|c|}
\hline & & Study design & Type of surgical procedure & $\begin{array}{l}\text { Number of } \\
\text { patients }\end{array}$ & Prophylaxis & $\begin{array}{l}\text { Incidence } \\
\text { of VTE }\end{array}$ & $\begin{array}{c}\text { Incidence of } \\
\text { symptomatic } \\
\text { PTE } \\
\end{array}$ & Diagnostic method \\
\hline 1 & Yoshioka et a ${ }^{10}$ & $\begin{array}{l}\text { Comparative } \\
\text { prospective }\end{array}$ & $\begin{array}{l}\text { Lumbar or lower thoracic } \\
\text { decompression with or } \\
\text { without instrumentation } \\
\text { Cervical decompression with } \\
\text { or without instrumentation } \\
\text { Spinal tumors }\end{array}$ & 340 & $\begin{array}{c}\text { Mechanical (compression } \\
\text { stockings and intermittent } \\
\text { pneumatic compression } \\
\text { devices) }\end{array}$ & $13.5 \%$ & $2.9 \%$ & Duplex US \\
\hline 2 & Oglesby et al ${ }^{11}$ & $\begin{array}{c}\text { Retrospective } \\
\text { database analysis }\end{array}$ & $\begin{array}{c}\text { Posterior and anterior cervical } \\
\text { fusion Posterior cervical } \\
\text { decompression }\end{array}$ & 273,396 & Not available & $0.38 \%$ & $0.15 \%$ & Not available \\
\hline 3 & Fineberg et $a \Upsilon^{2}$ & $\begin{array}{c}\text { Retrospective } \\
\text { database analysis }\end{array}$ & $\begin{array}{c}\text { Lumbar fusion or } \\
\text { decompression }\end{array}$ & 578,457 & Not available & $0.34 \%$ & $0.18 \%$ & Not available \\
\hline 4 & Al-Dujaili et $a^{l^{3}}$ & $\begin{array}{l}\text { Single center } \\
\text { prospective }\end{array}$ & $\begin{array}{l}\text { Spinal sugery (excluding } \\
\text { facetary inflitration, } \\
\text { vertebroplasty, } \\
\text { epidural injection, and } \\
\text { thermocoagulation of the } \\
\text { medial branch) } \\
\end{array}$ & 158 & $\begin{array}{c}\text { Mechanical } \\
\text { (compression stockings) } \\
\text { Chemical (low molecular } \\
\text { weight heparin) }\end{array}$ & $0.63 \%$ & Zero & $\begin{array}{c}\text { Clinical and Doppler } \\
\text { US }\end{array}$ \\
\hline 5 & Gephart et $a l^{14}$ & $\begin{array}{c}\text { Retrospective } \\
\text { database analysis }\end{array}$ & Spinal fusion & 430,081 & Not available & $0.4 \%$ & not available & Not available \\
\hline 6 & Kim et $a l^{15}$ & $\begin{array}{c}\text { Retrospective } \\
\text { database analysis }\end{array}$ & Spinal fusion & 3331 & Not available & $0.24 \%$ & $1 \%$ & Spiral CT \\
\hline 7 & Takahashi et a/ ${ }^{16}$ & $\begin{array}{c}\text { Retrospective } \\
\text { database analysis }\end{array}$ & $\begin{array}{l}\text { Lumbar fusion or } \\
\text { decompression }\end{array}$ & 1975 & $\begin{array}{c}\text { Without prophylaxis } \\
\text { Intermittent pneumatic } \\
\text { compression devices and } \\
\text { compression stockings }\end{array}$ & $19 \%$ & $0.56 \%$ & D-Dimer \\
\hline 8 & $\begin{array}{c}\text { Cunningham } \\
\text { et al }\end{array}$ & $\begin{array}{c}\text { Retrospective } \\
\text { database analysis }\end{array}$ & Spinal surgery & 3870 & $\begin{array}{l}\text { Without prophylaxis } \\
\text { Chemoprophylaxis }\end{array}$ & $0.28 \%$ & $0.31 \%$ & Not available \\
\hline 9 & Yoshiiwa et a ${ }^{18}$ & $\begin{array}{c}\text { Retrospective } \\
\text { database analysis }\end{array}$ & Spinal surgery & 88 & $\begin{array}{c}\text { Mechanical (compression } \\
\text { stockings and intermittent } \\
\text { pneumatic compression } \\
\text { devices) }\end{array}$ & $5.68 \%$ & $2.27 \%$ & D-DImer \\
\hline 10 & Smith et $a \Gamma^{19}$ & $\begin{array}{l}\text { Retrospective } \\
\text { analysis of } \\
\text { prospectively } \\
\text { collected data }\end{array}$ & $\begin{array}{l}\text { Lumbar microdiscectomy } \\
\text { Anterior cervical fusion } \\
\text { Lumbar decompression }\end{array}$ & 108,419 & Not available & $0.12 \%$ & $0.14 \%$ & Not available \\
\hline 11 & Schizas et $a^{20}$ & $\begin{array}{l}\text { Single center } \\
\text { prospective }\end{array}$ & $\begin{array}{l}\text { Lumbar fusion or } \\
\text { decompression }\end{array}$ & 270 & $\begin{array}{c}\text { Compression stockings } \\
\text { and low molecular weight } \\
\text { heparin }\end{array}$ & $\begin{array}{c}\text { not } \\
\text { available }\end{array}$ & $2.22 \%$ & Spiral CT \\
\hline 12 & Piasecki et a ${ }^{R 1}$ & $\begin{array}{l}\text { Single center } \\
\text { prospective }\end{array}$ & $\begin{array}{l}\text { Anterior posterior } \\
\text { reconstruction of spinal } \\
\text { deformity }\end{array}$ & 66 & $\begin{array}{c}\text { Mechanical (compression } \\
\text { stockings and intermittent } \\
\text { pneumatic compression } \\
\text { devices) }\end{array}$ & $9.1 \%$ & $7.6 \%$ & $\begin{array}{l}\text { Magnetic resonance } \\
\text { venography, Doppler } \\
\text { US, and Spiral CT }\end{array}$ \\
\hline 13 & Epstein $^{22}$ & $\begin{array}{l}\text { Single center } \\
\text { prospective }\end{array}$ & $\begin{array}{c}\text { Posterior fusion with } \\
\text { instrumentation and } \\
\text { laminectomy }\end{array}$ & 139 & Compression stockings & $2.8 \%$ & $0.7 \%$ & Doppler US \\
\hline 14 & $\begin{array}{c}\text { Oskouian and } \\
\text { Johnson }\end{array}$ & $\begin{array}{c}\text { Retrospective } \\
\text { database analysis }\end{array}$ & $\begin{array}{c}\text { Anterior thoracic and lumbar } \\
\text { spinal reconstruction }\end{array}$ & 207 & Not available & $2.42 \%$ & $0.48 \%$ & Not available \\
\hline 15 & Oda et $a^{R 4}$ & $\begin{array}{c}\text { Single center } \\
\text { prospective }\end{array}$ & Posterior spinal surgery & 110 & Without prophylaxis & $15.5 \%$ & $0 \%$ & $\begin{array}{c}\text { Bilateral ascending } \\
\text { venography }\end{array}$ \\
\hline 16 & Lee et $a^{25}$ & $\begin{array}{l}\text { Single center } \\
\text { prospective }\end{array}$ & Major spinal surgery & 313 & Without prophylaxis & $1.3 \%$ & $0 \%$ & Duplex US \\
\hline 17 & Dearborn et $a^{R 6}$ & $\begin{array}{c}\text { Retrospective } \\
\text { database analysis }\end{array}$ & Major spinal surgery & 116 & $\begin{array}{c}\text { Mechanical (compression } \\
\text { stockings and intermittent } \\
\text { pneumatic compression } \\
\text { devices) }\end{array}$ & $0.86 \%$ & $2.2 \%$ & Duplex US \\
\hline 18 & $\begin{array}{c}\text { Rajaraman } \\
\text { et a } \text { R }^{7} \\
\end{array}$ & $\begin{array}{l}\text { Single center } \\
\text { prospective }\end{array}$ & Anterior spinal surgery & 50 & Not available & $1.67 \%$ & $0 \%$ & Doppler US \\
\hline 19 & Wood et aR8 & $\begin{array}{l}\text { Prospective, } \\
\text { comparative, and } \\
\text { randomized }\end{array}$ & Major spinal surgery & 136 & $\begin{array}{c}\text { Pneumatic compression } \\
\text { stockings or pneumatic } \\
\text { thigh compression } \\
\text { bandages }\end{array}$ & $1.47 \%$ & $0.74 \%$ & Duplex US \\
\hline 20 & Rokito et $a^{29}$ & $\begin{array}{l}\text { Single center } \\
\text { prospective }\end{array}$ & Major spinal surgery & 329 & $\begin{array}{l}\text { Compression stockings of } \\
\text { the thigh, calf, or a low dose } \\
\text { of coumadin }\end{array}$ & $0.3 \%$ & $0 \%$ & Doppler US \\
\hline 21 & Nelson et $a^{\beta 0}$ & $\begin{array}{l}\text { Single center } \\
\text { prospective }\end{array}$ & Posterior spinal fusion & 117 & $\begin{array}{c}\text { Compression stockings } \\
\text { and intermittent pneumatic } \\
\text { compression pumps }\end{array}$ & $0 \%$ & $0 \%$ & Duplex US \\
\hline 22 & Smith et $a^{\beta 1}$ & $\begin{array}{l}\text { Single center } \\
\text { prospective }\end{array}$ & Spinal reconstruction & 317 & $\begin{array}{l}\text { Compression stockings } \\
\text { and intermittent pneumatic } \\
\text { compression devices }\end{array}$ & $0.95 \%$ & $0.32 \%$ & Duplex US \\
\hline 23 & Ferree $^{32}$ & $\begin{array}{l}\text { Single center } \\
\text { prospective }\end{array}$ & Lumbar laminectomy & 60 & Compression stockings & $5 \%$ & $0 \%$ & Not available \\
\hline 24 & $\begin{array}{l}\text { Ferree and } \\
\text { Wright }^{33}\end{array}$ & $\begin{array}{l}\text { Single center } \\
\text { prospective }\end{array}$ & Posterior spinal surgery & 185 & $\begin{array}{c}\text { Elastic compression } \\
\text { stockings or intermittent } \\
\text { pneumatic compression } \\
\text { devices } \\
\end{array}$ & $2.16 \%$ & not available & Duplex US \\
\hline 25 & Ferree et $a^{\beta 4}$ & $\begin{array}{l}\text { Single center } \\
\text { prospective }\end{array}$ & Spinal surgery & 86 & Not available & $6 \%$ & not available & Not available \\
\hline 26 & $\begin{array}{c}\text { West and } \\
\text { Anderson }{ }^{35}\end{array}$ & $\begin{array}{l}\text { Single center } \\
\text { prospective }\end{array}$ & Posterior spinal surgery & 41 & Not available & $14 \%$ & not available & Duplex Doppler US \\
\hline
\end{tabular}




\section{FINAL CONSIDERATIONS}

There is no single risk factor in spinal surgery, mainly due to the heterogeneity of approaches and pathologies. Therefore, it is not possible to indicate a standard thromboprophylaxis for spinal surgery as can be done for hip and knee surgeries. Additionally, chemoprophylaxis is still not safe due to the possibility of hemorrhagic complications. Therefore, it falls to the spinal surgeon to analyze the risk of DVT/PTE individually for each specific case.

Well-controlled prospective studies are also necessary to correctly identify the real incidence of DVT in high-risk patients, as well as to define the best type of prophylaxis to be indicated. In addition to determining the safest time to begin pharmacological therapy, it is also necessary to confirm the efficiency and the possible consequences of chemical prophylaxis, which is currently widely used in clinical practice, but still without evidence of its efficiency and safety.

All authors declare no potential conflict of interest concerning this article.

\section{REFERENCES}

1. Kearon C. Natural History of venous thromboembolism. Circulation. 2003;107(23 Suppl 1):I-22-30.

2. Goldhaber SZ, Visani L, De Rosa M. Acute pulmonary embolism: clinical outcomes in the International Cooperative Pulmonary Embolism Registry (ICOPER). Lancet. 1999;353(9162):1386-9.

3. Terra-Filho M, Menna-Barreto SS. Recommendations for the management of pulmonary thromboembolism, 2010. J Bras Pneumol. 2010:36:1-3.

4. Haas S. Deep vein thrombosis: beyond the operating table. Orthopedics. 2000;23(6 Suppl):S629-32.

5. Catre MG. Anticoagulation in spinal surgery. A critical review of the literature. Can J Surg J Can Chir. 1997;40(6):413-9.

6. Cordell-Smith JA, Williams SC, Harper WM, Gregg PJ. Lower limb arthroplasty complicated by deep venous thrombosis. Prevalence and subjective outcome. J Bone Joint Surg Br. 2004;86(1):99-101.

7. Bryson DJ, Uzoigwe CE, Braybrooke J. Thromboprophylaxis in spinal surgery: a survey. J Orthop Surg. 2012;7:14.

8. Geerts WH, Bergqvist D, Pineo GF Heit JA, Samama CM, Lassen MR, et al. Prevention of Venous Thromboembolism*American College of Chest Physicians Evidence-Based Clinical Practice Guidelines (8th Edition). Chest J. 2008;133(Suppl 6):S381-453.

9. Glotzbecker MP, Bono CM, Wood KB, Harris MB. Postoperative spinal epidural hematoma: a systematic review. Spine (Phila Pa 1976). 2010;35(10):E413-20.

10. Yoshioka K, Murakami H, Demura S, Kato S, Hayashi H, Inoue K, et al. Comparative study of the prevalence of venous thromboembolism after elective spinal surgery. Orthopedics. 2013;36(2):e223-8.

11. Oglesby M, Fineberg SJ, Patel AA, Pelton MA, Singh K. The incidence and mortality of thromboembolic events in cervical spine surgery. Spine (Phila Pa 1976). 2013:38(9):E521-7.

12. Fineberg SJ, Oglesby M, Patel AA, Pelton MA, Singh K. The incidence and mortality of thromboembolic events in lumbar spine surgery. Spine (Phila Pa 1976). 2013;38(13):1154-9.

13. Al-Dujaili TM, Majer CN, Madhoun TE, Kassis SZ, Saleh AA. Deep venous thrombosis in spine surgery patients: incidence and hematoma formation. Int Surg. 2012:97(2):150-4.

14. Gephart MGH, Zygourakis CC, Arrigo RT, Kalanithi PSA, Lad SP, Boakye M. Venous thromboembolism after thoracic/thoracolumbar spinal fusion. World Neurosurg. 2012;78(5):545-52

15. Kim HJ, Walcott-Sapp S, Adler RS, Pavlov H, Boachie-Adjei O, Westrich GH. Thromboembolic Complications Following Spine Surgery Assessed with Spiral CT Scans: DVT/ PE Following Spine Surgery. HSS J Musculoskelet J Hosp Spec Surg. 2011;7(1):37-40.

16. Takahashi H, Yokoyama $Y$, lida $Y$, Terashima F, Hasegawa K, Saito T, et al. Incidence of venous thromboembolism after spine surgery. J Orthop Sci Off J Jpn Orthop Assoc. 2012;17(2):114-7.

17. Cunningham JE, Swamy G, Thomas KC. Does preoperative DVT chemoprophylaxis in spinal surgery affect the incidence of thromboembolic complications and spinal epidural hematomas? J Spinal Disord Tech. 2011;24(4):E31-4.

18. Yoshiiwa T, Miyazaki M, Takita C, Itonaga I, Tsumura H. Analysis of measured D-dimer levels for detection of deep venous thrombosis and pulmonary embolism after spinal surgery. J Spinal Disord Tech. 2011:24(4):E35-9.

19. Smith JS, Fu K-MG, Polly DW Jr, Sansur CA, Berven SH, Broadstone PA, et al. Complication rates of three common spine procedures and rates of thromboembolism following spine surgery based on 108,419 procedures: a report from the Scoliosis Research Society Morbidity and Mortality Committee. Spine (Phila Pa 1976). 2010;35(24):2140-9.

20. Schizas C Neumayer F, Kosmopoulos V. Incidence and management of pulmonary embolism following spinal surgery occurring while under chemical thromboprophylaxis. Eur Spine J. 2008;17(7):970-4.

21. Piasecki DP, Poynton AR, Mintz DN, Roh JS, Peterson MGE, Rawlins BA, et al. Thromboembolic disease after combined anterior/posterior reconstruction for adult spinal deformity: a prospective cohort study using magnetic resonance venography. Spine (Phila Pa 1976). 2008:33(6):668-72

22. Epstein NE. Efficacy of pneumatic compression stocking prophylaxis in the prevention of deep venous thrombosis and pulmonary embolism following 139 lumbar laminectomies

with instrumented fusions. J Spinal Disord Tech. 2006;19(1):28-31.

23. Oskouian RJ Jr, Johnson JP. Vascular complications in anterior thoracolumbar spinal re construction. J Neurosurg. 2002 Jan;96(1 Suppl):1-5.

24. Oda T, Fuji T, Kato Y, Fujita S, Kanemitsu N. Deep venous thrombosis after posterior spinal surgery. Spine (Phila Pa 1976). 2000;25(22):2962-7.

25. Lee HM, Suk KS, Moon SH, Kim DJ, Wang JM, Kim NH. Deep vein thrombosis after major spinal surgery: incidence in an East Asian population. Spine (Phila Pa 1976) 2000;25(14):1827-30

26. Dearborn JT, Hu SS, Tribus CB, Bradford DS. Thromboembolic complications after major thoracolumbar spine surgery. Spine (Phila Pa 1976). 1999;24(14):1471-6.

27. Rajaraman $V$, Vingan $R$, Roth $P$, Heary RF, Conklin L, Jacobs GB. Visceral and vascular complications resulting from anterior lumbar interbody fusion. J Neurosurg. 1999;91(Suppl 1):60-4

28. Wood KB, Kos PB, Abnet JK, Ista C. Prevention of deep-vein thrombosis after major spinal surgery: a comparison study of external devices. J Spinal Disord. 1997:10(3):209-14.

29. Rokito SE, Schwartz MC, Neuwirth MG. Deep vein thrombosis after major reconstructive spinal surgery. Spine (Phila Pa 1976). 1996;21(7):853-8.

30. Nelson LD Jr, Montgomery SP, Dameron TB Jr, Nelson RB. Deep vein thrombosis in lumbar spinal fusion: a prospective study of antiembolic and pneumatic compression stockings. J South Orthop Assoc. 1996:5(3):181-4.

31. Smith MD, Bressler EL, Lonstein JE, Winter R, Pinto MR, Denis F. Deep venous thrombosis and pulmonary embolism after major reconstructive operations on the spine. A prospective analysis of three hundred and seventeen patients. J Bone Joint Surg Am. 1994;76(7):980-5.

32. Ferree BA. Deep venous thrombosis following lumbar laminotomy and laminectomy. Orthopedics. 1994;17(1):35-8

33. Ferree BA, Wright AM. Deep venous thrombosis following posterior lumbar spinal surgery. Spine (Phila Pa 1976). 1993;18(8):1079-82

34. Ferree BA, Stern PJ, Jolson RS, Roberts JM 5th, Kahn A 3rd. Deep venous thrombosis after spinal surgery. Spine (Phila Pa 1976). 1993;18(3):315-9.

35. West JL 3rd, Anderson LD. Incidence of deep vein thrombosis in major adult spinal surgery. Spine (Phila Pa 1976). 1992:17(Suppl 8):S254-7.

36. Tromboembolismo venoso: profilaxia em pacientes clínicos - parte I. Rev Assoc Med Bras. 2009;55(2):102-5

37. Brambilla S, Ruosi C, La Maida GA, Caserta S. Prevention of venous thromboembolism in spinal surgery. Eur Spine J. 2004;13(1):1-8.

38. Raj D, Marshall RW. Prophylaxis against thromboembolism in spinal surgery. Arch Orthop Trauma Surg. 2008;128(12):1365-71.

39. Glotzbecker MP, Bono CM, Wood KB, Harris MB. Thromboembolic disease in spinal surgery: a systematic review. Spine (Phila Pa 1976). 2009;34(3):291-303.

40. Platzer $P$, Thalhammer $G$, Jaindl $M$, Obradovic $A$, Benesch $T$, Vecsei $V$, et al. Thromboembolic complications after spinal surgery in trauma patients. Acta Orthop. 2006;77(5):755-60

41. DeVries JG, Berlet GC. Understanding levels of evidence for scientific communication Foot Ankle Spec. 2010;3(4):205-9

42. Awad JN, Kebaish KM, Donigan J, Cohen DB, Kostuik JP. Analysis of the risk factors for the development of post-operative spinal epidural haematoma. J Bone Joint Surg Br. 2005;87(9):1248-52.

43. Kou J, Fischgrund J, Biddinger A, Herkowitz $\mathrm{H}$. Risk factors for spinal epidural hematoma after spinal surgery. Spine (Phila Pa 1976). 2002:27(15):1670-3.

44. Yi S, Yoon DH, Kim KN, Kim SH, Shin HC. Postoperative spinal epidural hematoma: risk factor and clinical outcome. Yonsei Med J. 2006;47(3):326-32

45. Spinal Cord Injury Thromboprophylaxis Investigators. Prevention of venous thromboembolism in the rehabilitation phase after spinal cord injury: prophylaxis with low-dose heparin or enoxaparin. J Trauma. 2003;54(6):1111-5.

46. Axelrod DA, Wakefield TW. Future directions in antithrombotic therapy: emphasis on venous thromboembolism. J Am Coll Surg. 2001;192(5):641-51 